\title{
COLLETERS IN Caryocar brasiliense (CARYOCARACEAE) ONTOGENESIS, ULTRASTRUCTURE AND SECRETION
}

\author{
PAIVA, E. A. S. ${ }^{1}$, and MACHADO, S. R. ${ }^{2}$ \\ ${ }^{1}$ Department of Botany, Institute of Biological Sciences, Federal University of Minas Gerais, \\ CEP 31270-901, Belo Horizonte, MG, Brazil \\ ${ }^{2}$ Department of Botany, Institute of Biosciences, UNESP, C. P. 510, CEP 18618-000, Botucatu, SP, Brazil \\ Correspondence to: Élder Antônio Sousa Paiva, Department of Botany, Institute of Biological Sciences, \\ Federal University of Minas Gerais, CEP 31270-901, Belo Horizonte, MG, Brazil, e-mail: epaiva@icb.ufmg.br \\ Received March 2, 2004 - Accepted September 17, 2004 - Distributed February 28, 2006
}

(With 19 figures)

\begin{abstract}
Colleters are widely distributed and have been reported in several taxa. However, the only report of colleters in the Caryocaraceae family is in Caryocar brasiliense. This study purports to describe the distribution, structure and ultrastructure of colleters in $C$. brasiliense. Vegetative shoot apices with stipules in different stages of development were collected, fixed, and processed by light, transmission and scanning electron microscopy. Colleters occur on the stipule adaxial face and are differentiated on younger stipules, remaining functional until senescence. Stipules are deciduous, falling before the beginning of leaf expansion. Colleter secretion is abundant, filling all the space delimited by the stipule. Colleter origin is mixed, involving the protoderm and ground meristem. In this species, colleters are finger-shaped, consisting of a column of non-secretory central cells and a secretory epithelium whose cells are arranged in palisades. Secretory epithelium cells show dense cytoplasm, rough endoplasmic reticulum (RER) segments, free ribosomes, mitochondria, and abundant well developed dictyosomes. The colleters central cell shows a flocculated cytoplasm and developed vacuole. These cells have a small lobated nucleus with an inconspicuous nucleolus. Mitochondria and RER stand out in the organelles. There is evidence of granulocrine secretion and colleter involvement with protection of the apical meristem and leaves in the initial stages of development.
\end{abstract}

Keywords: Caryocaraceae, cerrado vegetation, colleter, pequi, secretion.

RESUMO

\section{Ontogênese, ultra-estrutura e secreção dos coléteres de Caryocar brasiliense Camb. (Caryocaraceae)}

Os coléteres são amplamente distribuídos, com registros de sua ocorrência em diversas taxas, entretanto há apenas um registro de sua ocorrência na família Caryocaraceae, à qual pertence Caryocar brasiliense. Com o objetivo de descrever a distribuição, estrutura e ultra-estrutura dos coléteres de C. brasiliense, amostras de ápices caulinares com estípulas em várias fases de desenvolvimento foram coletadas, fixadas e processadas para estudos em microscopia de luz e eletrônica de transmissão e varredura. Os coléteres ocorrem exclusivamente na face adaxial das estípulas e diferenciam-se nas estípulas mais jovens, mantendose funcionais até a senescência. As estípulas são caducas, caindo antes do início da expansão das folhas. A secreção dos coléteres é abundante, preenchendo todo o espaço delimitado pela estípula. A origem dos coléteres é mista, envolvendo a protoderme e o meristema fundamental, sendo, portanto, considerados como emergências e não tricomas. Nesta espécie, os coléteres são digitiformes, formados por uma coluna de células centrais, não secretoras e por um epitélio secretor cujas células estão dispostas em paliçada. As células do epitélio secretor apresentam citoplasma denso, segmentos de retículo endoplasmático rugoso, ribossomos livres, mitocôndrias e abundância de dictiossomos, dos quais partem inúmeras vesículas possivelmente carregadas com produtos de secreção. As células centrais do coléter apresentam núcleo pouco volumoso e lobado, com nucléolo inconspícuo; o citoplasma é pouco denso, floculado e o vacuoma 
desenvolvido. Dentre as organelas presentes, destacam-se as mitocôndrias e segmentos de retículo endoplasmático rugoso. Há evidências de secreção granulócrina e do envolvimento dos coléteres com a proteção do meristema apical e folhas nos estádios iniciais do desenvolvimento.

Palavras-chave: Caryocaraceae, cerrado, coléter, pequi, secreção.

\section{INTRODUCTION}

Colleters are multicellular secretory structures that may occur in vegetative or reproductive shoot apices; their probable role is to protect meristems by secreting a viscous substance (Thomas, 1991). The developing meristem is completely covered with colleter exudate which protects it (Thomas \& Dave, 1989; Thomas, 1991). According to Dickison (2000), colleters are multicellular appendices or trichomes which produce a sticky secretion. Protection of bud shoots and young leaves seems to be the colleter's main function (Mueller, 1985; Thomas \& Dave, 1990; Thomas, 1991). Colleters differentiate early and are directed towards the meristem on the adaxial face of stipules and petioles, varying widely in shape, size, and cell composition (Thomas, 1991).

Colleters are reported in several Angiosperm families. In the order Malpighiales (APG, 2003), to which the Caryocaraceae belongs, the occurrence of colleters has been reported in Euphorbiaceae, Passifloraceae, Rhizophoraceae and Turneraceae (Thomas, 1991). Colleter occurrence in the Caryocaraceae has been recorded only in C. brasiliense (Rezende, 1998). This species, which is widely distributed throughout the "cerrados" of central Brazil, produces important edible fruits and has other secretory structures as, for example, extrafloral nectaries (Rezende 1998).

The objective of this paper is to describe the ontogenesis, structure, and some ultrastructural features of colleters in C. brasiliense.

\section{MATERIALS AND METHODS}

Caryocar brasiliense specimens were collected from the "cerrado" region of Botucatu, SP, Brazil (22 $2^{\circ} 53^{\prime} 11.4$ ' S; 48 $8^{\circ} 26^{\prime} 08.0^{\prime \prime} \mathrm{W}$ ). Fertile branches were sampled and deposited as voucher specimens in the "Irina D. Gemtchújnicov" Herbarium, (BOTU), Department of Botany, IB, UNESP, Botucatu, under number 23701.

For light microscopy, vegetative shoot apices specimens with stipules in different stages of development were fixed in Karnovsky mixture (Karnovsky, 1965), processed and infiltrated in historesin (Leica Embedding Kit), as per standard procedures. 5 to $10 \mu \mathrm{m}$ thick transverse and longitudinal sections were obtained by microtome. These were mounted on slides and stained with toluidine blue (O'Brien et al., 1964). For histochemical tests, sections were stained with Rutenium red for acid polysaccharides (Johansen, 1940); Sudan black B for lipids (Jensen 1962); and Bromophenol blue for proteins (Mazia et al., 1953).

For transmission electron microscopy (TEM), samples of the outermost stipule with colleters were fixed in Karnovsky mixture (Karnovsky, 1965), post-fixed in $1 \%$ osmium tetroxide $(0.1 \mathrm{M}$ phosphate buffer $\mathrm{pH}$ 7.2) for $2 \mathrm{~h}$, dehydrated by acetone series, and embedded in Araldite resin (Roland, 1978). Ultrathin sections were contrasted with uranyl acetate and lead citrate (Roland, 1978) and examined under a Phillips CM 100 transmission electron microscope (TEM) at $60 \mathrm{KV}$.

For scanning electron microscopy (SEM), samples were fixed in $2.5 \%$ glutaraldehyde, dehydrated by increasing ethyl alcohol series, and dried to the critical point with $\mathrm{CO}_{2}$ as the transition liquid. The samples were gold-coated as per Robards (1978), and examined by SEM (Philips 515).

\section{RESULTS}

\section{Location and structure}

C. brasiliense colleters occur on the adaxial face of stipules which protect the bud shoots. In this species, the stipules are deciduous and fall off as soon as the leaf starts to expand.

The colleters are long, clavate and with a variable length peduncle; they are randomly distributed on the basal third of the stipules (Figs. 1 to 3 ). Colleter diameter and length vary from $150 \mu \mathrm{m}$ to $250 \mu \mathrm{m}$, and $400 \mu \mathrm{m}$ to $600 \mu \mathrm{m}$, respectively. 
Colleter origin and differentiation occur in very young stipules when they are about $10 \%$ of their final size and protect bud shoots. Colleters are functional as soon as they are formed. In young colleters, initial secretion is fluid while secretion from the colleters of the outermost stipule pair is abundant, viscous and whitish.

In the stipule protecting the bud shoot and the first pair of leaf primordia, small groups of protodermic cells are visible which differ from the others by presenting dense cytoplasm and being more anticlinally elongated (Figs. 7 and 8). The lower tissue layer cells show divisions in different planes and produce a bulge, which are colleters in formation (Fig. 8). In adult colleters, these cells expand axially and become vacuolated, forming a central column. The protodermic cells go through successive anticlinal divisions and expand, forming the secretory tissue whose cells are arranged in palisades (Figs. 9 and 10).

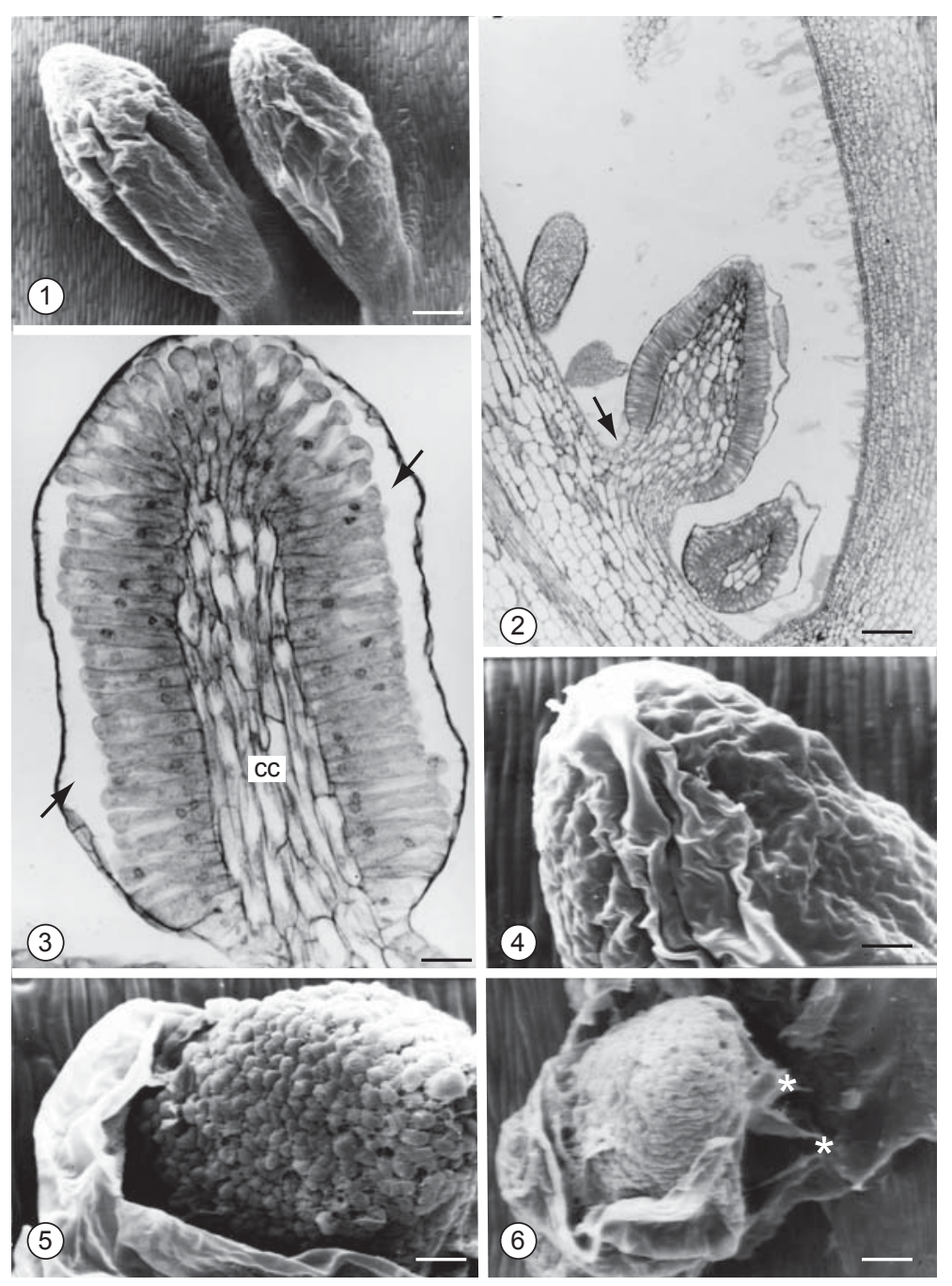

Figs. 1-6 - In 1, SEM photograph showing a general view of colleters; in 2 and 3, photomicrographs of colleters, in 2 note their arrangement on the adaxial face of the stipule and the short peduncle (arrow); in 3, detail of colleter showing central cells (cc) and secretory epithelium; note cuticle displacement and subcuticular space (arrow); from 4 to 6, SEM photographs of colleters in the secretory stage; note the cuticle's loose aspect; and in 5 and 6, colleter with cuticular rupture, exposing the secretory cells and the wide subcuticular space; and in 6 secretion residues (*) (Bar $=100 \mu \mathrm{m} ; 100 \mu \mathrm{m} ; 25 \mu \mathrm{m} ; 50 \mu \mathrm{m}$; $50 \mu \mathrm{m} ; 50 \mu \mathrm{m}$, Figs. 1-6, respectively). 
Colleter longitudinal sections show a column of central cells and a unistratified secretory epithelium, which consist of cells arranged in palisade (Figs. 3 and 10). No vascular elements were found in the colleters. The central column cells are axially elongated, vacuolated, and devoid of pigments or reserve substances (Fig. 3).

The secretory epithelium cells cover the entire colleter except for the peduncle. These cells are long, tubular, thin walled, and with dense cytoplasm and evident nuclei. The nucleus is globular and occupies the central cell region, while the vacuole generally occurs in the apical third of the cell (Fig. 10). The cuticle covering the secretory epithelium is uniformly thick along its entire length, showing no evidence of pores or channels. It frequently detaches itself from the cell wall, leaving an ample subcuticular space where secretion product accumulates (Figs. 3 to 6).

Pectic compounds, lipid, and protein were detected in secretion samples of the $C$. brasiliense colleter.

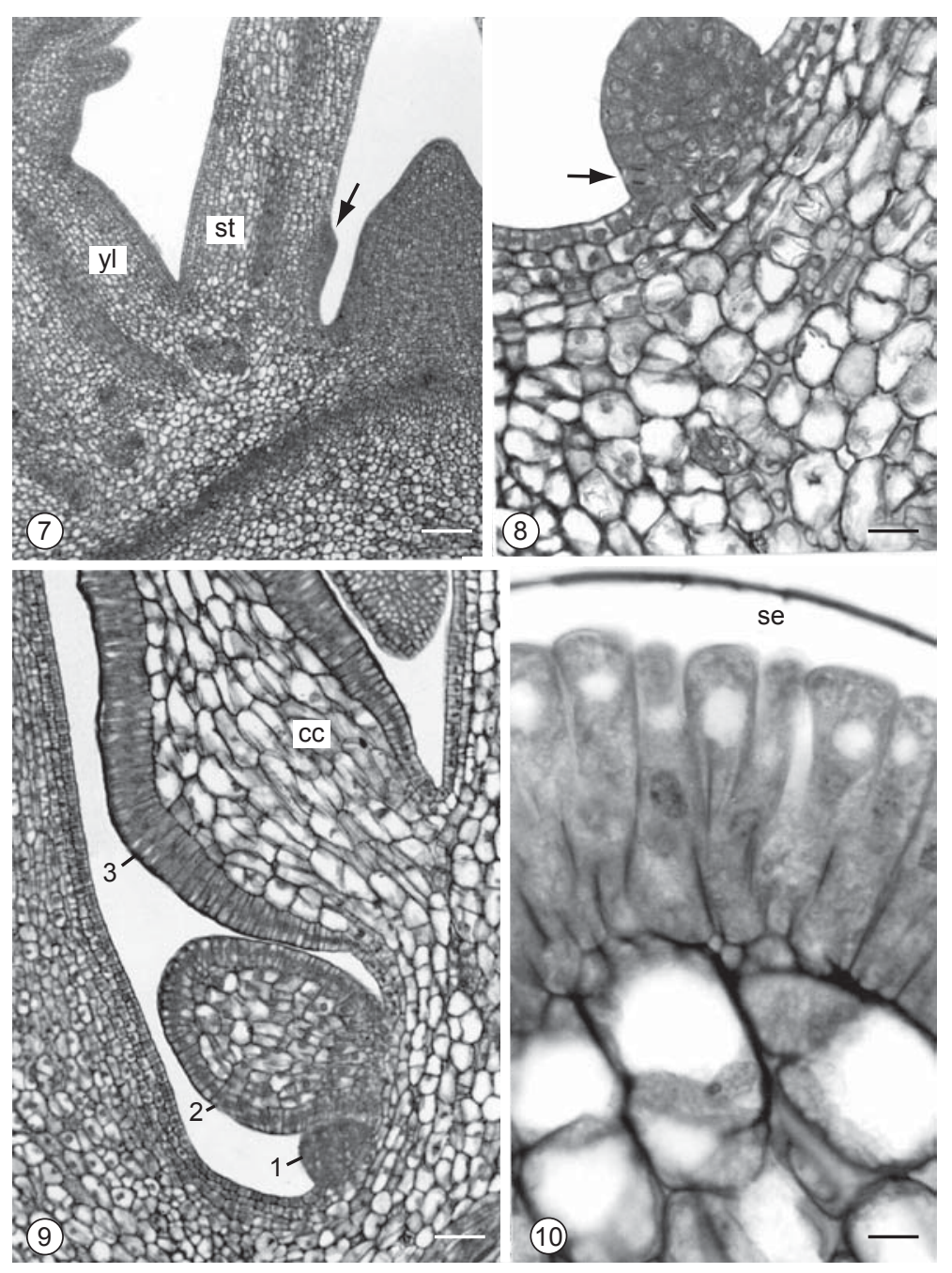

Figs. 7-10 - Photomicrographs of vegetative shoot apex and colleter longitudinal sections. In 7, note in the innermost stipule (st) the beginning of colleter formation (arrow) and a young leaf (yl); in 8, detail showing protoderm and subjacent tissue in colleter formation; the arrow indicates an anticlinal division in the protoderm; in 9, colleters in different stages of development $(1,2,3)$; note the central cells (cc) considerable expansion; and in 10, detail of adult colleter secretory epithelium; note cytoplasmic density and subcuticular space (se) (Bar $=100 \mu \mathrm{m} ; 25 \mu \mathrm{m} ; 50 \mu \mathrm{m}$; and $10 \mu \mathrm{m}$; Figs. 7-10, respectively). 


\section{Ultrastructural aspects}

The secretory epithelium cells have dense and abundant cytoplasm, RER segments, mitochondria, and abundant dictyosomes; the vacuoles are small (Figs. 11-13). Dictyosomes have a high and variable number of cisternae, from which many globular vesicles sprout and disperse throughout the cytosol; they are more concentrated in the apical part of the secretory cells (Fig 13). Justaposition of dictyosomes and RER segments is common.
Some secretory cells display an increase in vacuome and darkening of the cytosol. In these cells, dictyosomes are even more evident and more active, as indicated by the number of vesicles that spout from them (Fig. 14).

The colleter central cells have small lobated nuclei with an inconspicuous nucleolus (Fig. 17). The cytoplasm is less dense, flocculated, and the vacuome is developed (Fig. 15). These cells contain a large central vacuole and many smaller dispersed
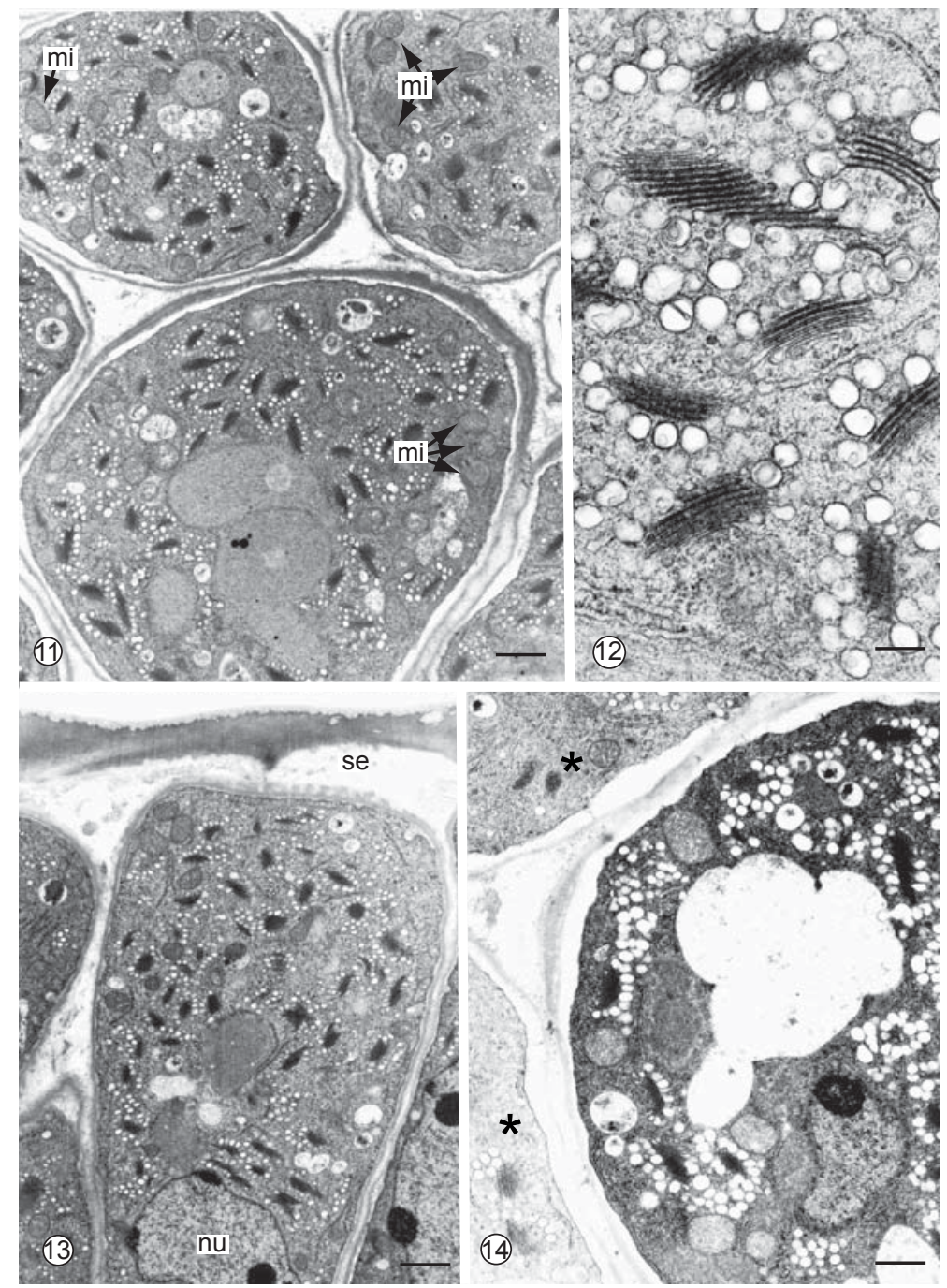

Figs. 11-14 - TEM photographs of secretory epithelium cells. In 11, note dense cytoplasm, mitochondria (mi), RER segments, and numerous dictyosomes; in 12, detail showing dictyosomes with vesicles; note the vesicles' electron-opaque content; in 13, cell longitudinal section showing organelle distribution on the apical face; note secretion accumulation in the subcuticular space (se) and central nucleus (nu); and in 14, cell cytoplasm darkening, increased vacuome, and greater number of dictyosome vesicles; at side note normal cells $(*)$. (Bar $=2 \mu \mathrm{m} ; 0.3 \mu \mathrm{m} ; 2 \mu \mathrm{m} ; 1 \mu \mathrm{m}$; Figs. 11-14, respectively). 
ones. In relation to the organelles, the mitochondria and RER segments stand out. The mitochondria are up to $5 \mu \mathrm{m}$ long and with well-developed cristae (Fig. 16).

The central cells are connected through the plasmodesmata, arranged preferentially on terminal walls; lateral connections are not very common. The symplastic connection between the central and secretory epithelial cells is made through numerous primary pit fields with plasmodesmata (Figs. 18 and 19).

\section{DISCUSSION}

The first report of colleter occurrence in C. brasiliense was published by Rezende (1998). According to Rezende (1998), the colleters are present on the scales which protect the bud shoots. However, Prance \& Silva (1973) consider these laminar structures to be stipules, as we do in this work. C. brasiliense stipules are deciduous (Prance \& Silva, 1973) and fall as soon as the young leaves are released from inside and start expanding. The stipules' role in the protection of bud shoots and
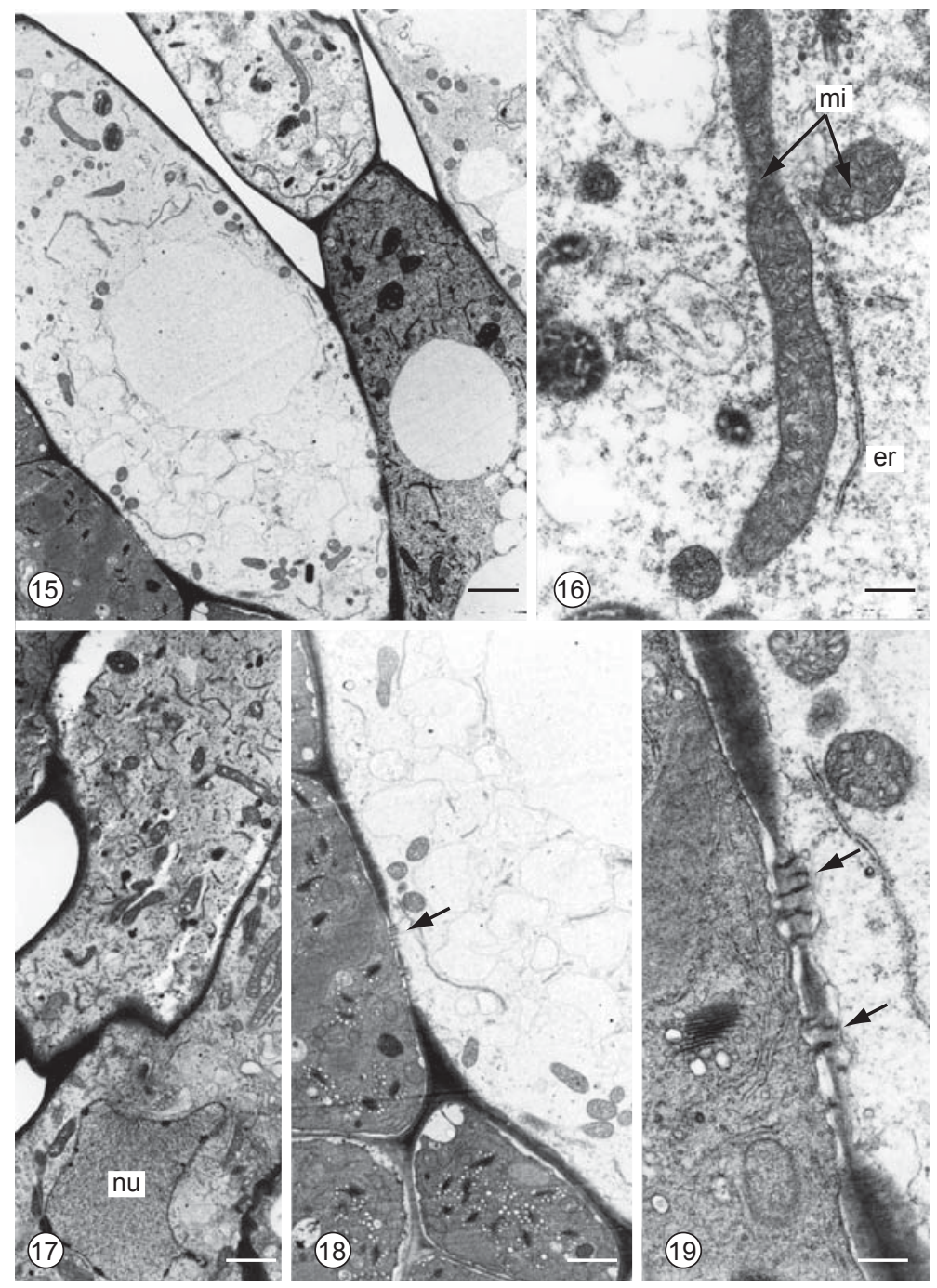

Figs. 15-19 - TEM photographs of colleter central cells. In 15, general view of central cells; in 16, detail of mitochondria (mi) and RER segment (er); in 17, central cells with lobated nucleus (nu) without evident nucleolus, characteristic of these cells; and in 18 and 19, detail of connection between central cell and secretory epithelium; note the difference in cytoplasmic density and presence of plasmodesmata (arrows). ( $\mathrm{Bar}=3 \mu \mathrm{m} ; 0.5 \mu \mathrm{m} ; 2 \mu \mathrm{m} ; 2 \mu \mathrm{m} ; 0.5 \mu \mathrm{m}$; Figs. 15-19, respectively). 
young leaves (Lubbock, 1890) is evident in this species. The presence of colleters on these stipules confirms their protective role. According to Thomas (1991), bud shoot protection is the most probable function of colleters. Since the number of colleters in $C$. brasiliense varies, this does not constitute a relevant element for taxonomic purposes. This variation in colleter number is also reported by Thomas (1991). Colleters on C. brasiliense leaf primordia, which have been reported by Rezende (1998), are similar to the stipular ones.

The colleters in $C$. brasiliense stipules are similar to the "Standard" described by Lersten (1974). "Standard" type colleters are finger shaped, with a short peduncle and a long secretory head, as found in this study. According to Thomas (1991), this type of colleter is very common.

The protoderm and ground meristem participate in the formation of $C$. brasiliense colleters; that is why they cannot be considered trichomes, as suggested by Solereder (1908). This seems to be common for the "Standard" type of colleters, as Patel \& Zaveri (1975) found in Coffea arabica, Mohan \& Inandar (1986) in Plumeria rubra, and Appezzato-da-Glória \& Estelita (2000) in Mandevilla spp.

In $C$. brasiliense the colleters differentiate from the stipules that protect the shoots, and they begin their secretory activity when the stipules are still young, protecting the leaf primordia which are immersed in secretion. This finding is in agreement with Mueller (1985) and Thomas (1991).

The absence of pores or channels in the cuticle leads us to suppose that colleter secretion release occurs by cuticle rupture as the result of pressure exerted by secretion accumulated in the subcuticular space (Mohan \& Inandar, 1986; Paiva et al., 2001).

C. brasiliense colleters are not deciduous, a marked characteristic of these structures in several species and organs (Thomas, 1991). This may be because of early stipule senescence, as in Hymenaea stigonocarpa (Paiva \& Machado, 2006). In older colleters, dark cytoplasm cells constitute evidence of programmed cell death, according to Schussler \& Longstreth (1996).

Ruthenium red intense reaction indicates acid polysaccharides in the secretion, allowing us to infer that they are responsible for most of the secreted volume, as observed by Meyberg
(1988) in the mucilage produced by trichomes in Nymphoides peltata. Lipid compounds present in colleter secretion, as in $C$. brasiliense, are common in colleters (Mohan \& Inandar, 1986; Thomas \& Dave, 1989; Appezzato-da-Glória \& Estelita, 2000). In $C$. brasiliense, proteins in colleter secretion were only detected qualitatively; however, the intensity of the reaction suggests that the quantity is small, with a possible enzymatic function. The presence of proteins in colleter secretion has also been reported by several authors (Horner \& Lersten, 1968; Mohan \& Inandar, 1986; Thomas \& Dave, 1989); however, their function in protecting meristem apices still requires study.

The large number of dictyosomes in colleter secretory phase is evidence of polysaccharide secretion (Andreeva et al., 1998) and the vesicles sprouting from these organelles, possibly loaded with secretion products, indicate that secretion in C. brasiliense is granulocrine (see Fahn, 1979).

The relatively large number of mitochondria both in central and secretory epithelial cells should be attributed to their intense metabolic activity. The presence of these organelles is a marked characteristic of these cells (Lüttge, 1971; Fahn, 1988). Increased mitochondria cell population in secretory phase is described by Mohan \& Inandar (1986).

C. brasiliense colleters do not show vascularization similar to other species with standard type colleters, as Plumeria rubra (Mohan \& Inandar, 1986) and Allamanda cathartica (Thomas \& Dave, 1989). The central cells establish symplastic connections with each other, especially through their terminal walls; they connect with secretory epithelium cells by lateral walls. Thus, central cells may act in transporting precursors of colleter secretion products and can be considered a type of transport-specialized parenchyma cells. The substantial number and size of mitochondria in these cells is also evidence of high metabolic activity; we assume that they may play an active role in transportation.

C. brasiliense colleters are a good model for secretion studies in plants due to their intense secretory activity. They can also contribute to studies of dictyosome performance in the secretory process. Indeed, the central cells could be a model for a short-distance transport of precursor products of secretion. 
Considering that colleter occurrence in Caryocaraceae was verified at this time only in C. brasiliense, additional studies are necessary to ascertain the distribution and taxonomical importance of this structure in this family. Position, short-life, and secretory composition are evidence that these structures can protect the bud shoots.

Acknowledgments — We are indebted to Fundação de Amparo a Pesquisa do Estado de São Paulo, FAPESP, for its financial support (Proc. 00/12469-3) and to the staff of Centro de Microscopia Eletrônica, Instituto de Biociências, UNESP, for their help in the preparation of samples.

\section{REFERENCES}

ANDREEVA, A. V., KUTUZOV, M. A., EVANS, D. E. \& HAWES, C. R., 1998, The structure and function of Golgi apparatus: a hundred years of questions. J. Exp. Bot., 49(325): 1281-1291.

APG, 2003, An update of the Angiosperm Phylogeny Group classification for the orders and families of flowering plants: APG II. Bot. J. Linn. Soc., 141(4): 399-436.

APPEZZATO-DA-GLORIA, B. \& ESTELITA, M. E. M., 2000, Development, structure and distribution of colleters in Mandevilla illustris and M. velutina (Apocynaceae). Rev. Bras. Bot., 23(2): 113-120.

DICKISON, W. C., 2000, Integrative Plant Anatomy. Academic Press, San Diego, 533p.

FAHN, A., 1979, Secretory Tissues in Plants. Academic Press, New York, 302p.

FAHN, A., 1988, Secretory tissues in vascular plants. New Phytol., 108: 229-257.

HORNER, H. T. Jr. \& LERSTEN, N. R., 1968, Development, structure and function of secretory trichomes in Psychotria bacteriophila (Rubiaceae). Am. J. Bot., 55(9): 1089-1099.

JENSEN, W. A., 1962, Botanical histochemistry: principles and practice. W. H. Freeman, San Francisco, 408p.

JOHANSEN, D. A., 1940, Plant microtechnique. McGraw-Hill Book, New York, 523p.

KARNOVSKY, M. J., 1965, A formaldehyde-glutaraldehyde fixative of light osmolality for use in electron microscopy. J. Cell Biol., 27: 137A-138A.

LERSTEN, N. R., 1974, Morphology and distribution of colleters and crystals in relation to the taxonomy and bacterial leaf nodule symbiosis of Psychotria (Rubiaceae). Am. J. Bot., 61(9): 973-981.

LUBBOCK, J., 1890, On stipules, their form and function. $J$. Linn. Soc., 28: 217-243.

LÜTTGE, U., 1971, Structure and function of plant glands. Ann. Rev. Plant Phys., 22: 23-44.
MAZIA, D., BREWER, P. A. \& ALFERT, M., 1953, The cytochemistry staining and measurement of protein with mercuric bromophenol blue. Biol. Bull., 104: 57-67.

MEYBERG, M., 1988, Cytochemistry and ultrastructure of the mucilage secreting trichomes of Nymphoides peltata (Menyanthaceae). Ann. Bot., 62: 537-547.

MOHAN, J. S. S. \& INAMDAR, J. A., 1986, Ultrastructure and secretion of extrafloral nectaries of Plumeria rubra L. Ann. Bot., 57: 389-401.

MUELLER, R. J., 1985, Determinate branch development in Alstonia scholaris (Apocynaceae) - the plagiotropic module. Am. J. Bot., 72: 1435-1444.

O'BRIEN, T. P., FEDER, N. \& McCULLY, M. E., 1964, Polychromatic staining of plant cell walls by toluidine blue. Protoplasma, 59: 368-373.

PAIVA, E. A. S., MORAIS, H. C., ISAIAS, R. M. S., ROCHA, D. M. S. \& OLIVEIRA, P. E., 2001, Occurence and structure of extrafloral nectaries in Pterodon pubescens Benth. and Pterodon polygalaeflorus Benth. (FabaceaePapilionoideae). Pesq. Agropec. Bras., 36(2): 219-224.

PAIVA, E. A. S \& MACHADO, S. R., 2006, Ontogenesis, structure and ultrastructure of Hymenaea stigonocarpa (Fabaceae-Caesalpinioideae) colleters. Rev. Biol. Trop. (in press).

PATEL, J. D. \& ZAVERI, M., 1975, Development of leaf and stipular glands in Coffea arabica. Flora, 164: 11-18.

PRANCE, G. T. \& SILVA, M. F., 1973, A monograph of Caryocaraceae. Flora Neotropica, 12: 1-75.

REZENDE, M. H., 1998, Anatomia dos órgãos vegetativos, da flor e estruturas secretoras de Caryocar brasiliense Camb. (Caryocaraceae). Tese (D. S.), Universidade de São Paulo, São Paulo, 91p.

ROBARDS, A. W., 1978, An introduction to techniques for scanning electron microscopy of plant cells, pp. 343-403. In: J. L. Hall (ed). Electron Microscopy and Cytochemistry of Plant Cells. New York, Elsevier, 465p.

ROLAND, J. C., 1978, General preparations and staining of thin sections, pp. 1-62. In: J. L. Hall (ed) Electron Microscopy and Cytochemistry of Plant Cells. New York: Elsevier, $465 \mathrm{p}$.

SCHUSSLER, E. E. \& LONGSTRETH, D. J., 1996, Aerenchyma develops by cell lysis in roots and cell separation in leaf petioles in Sagittaria lancifolia (Alismataceae). Am. J. Bot., 83(10): 1266-1273.

SOLEREDER, H., 1908, Systematic Anatomy of the Dicotiledons. Clarendon Press, Oxford, $2^{\circ}$ vol., 1182 p.

THOMAS, V., 1991, Structural, functional and phylogenetic aspects of the colleter. Ann. Bot., 68: 287-305.

THOMAS, V. \& DAVE, Y., 1989, Histochemistry and senescence of colleters of Alamanda cathartica (Apocynaceae). Ann. Bot., 64: 201-203.

THOMAS, V. \& DAVE, Y., 1990, Mode of secretion in the colleters of Alstonia scholaris (Apocynaceae). Phyton, 30(2): 209-212 